\title{
Maitotilojen kannattavuuserojen syyt
}

\author{
Arto Latukka
}

\section{MTT Taloustutkimus, Luutnantintie 13,00410 Helsinki,arto.latukka@mtt.fi}

Tutkimusaineistona on MTT Taloustutkimuksen kannattavuuskirjanpitoaineiston tilivuoden 2008 maitotilat. Keskimäärin kannattavuuskerroin oli näillä 0,62 ja vaihteli pienimmän 7 lehmän tilakokoluokan 0,43:sta 93 lehmän tilakokoluokan 0,8:aan. Jotta pelkkä tilakoko ei olisi syynä kannattavuuseroihin, tarkastelu tulee tehdä tilakokoluokittain. Seuraavassa tarkastellaan kokoluokkaa "suuri", jossa on keskimäärin 32 lehmää ja kannattavuuskerroin 0,71. Tuet muodostavat keskimäärin 34 prosenttia kokonaistuotosta. Ryhmän kannattavuus on A/B -tukialueilla keskimäärin 0,67 ja C-tukialueilla vain hiukan suurempi, 0,71. Siksi tarkastelua ei ole tarvetta tehdä tukialueittain.

Kannattavuusvaihtelu yksittäisen kokoluokan sisälläkin on suuri. Parhaimman viidenneksen kannattavuuskerroin on 1,32 ja heikoimman negatiivinen, -0,01. Parhaimman viidenneksen hyvät tulokset johtuvat osin poikkeuksellisista onnistumisista ja ne kääntyvät laskuun jo seuraavana vuonna. Heikoimmalla viidenneksellä omavaraisuusaste on 39 prosenttia eli kannattavuutta heikentävät juuri tehdyt investoinnit. Näillä puolestaan kannattavuus kääntyy investointikustannusten pienentyessä nousuun. Äärimmäisten viidennesten (ja myös neljännesten) poikkileikkaustarkastelu yliarvioi kannattavuuseroja ja näiden ryhmien perusteella ei löydy todellisia tuotannosta aiheutuvia syitä kannattavuuseroihin.

MTT:n Taloustohtorin maa- ja puutarhatalous -verkkopalvelun hajontatarkasteluissa jätetään sekä heikot- että hyvät -ryhmistä äärimmäiset kymmenen prosenttia tiloista pois ja kumpikin ryhmä sisältää seuraavat 20 prosenttia tiloista. Heikot -ryhmän tulokset eivät kuvaa enää pelkästään juuri investoineita tiloja, sillä niiden omavaraisuusaste on 65 ja kannattavuuskerroin 0,36 . Hyvät -ryhmän kerroin on 1,13 . Nämä ryhmät pysyvät kannattavuustasoillaan pidempiaikaisesti ja niiden perusteella voidaan paremmin tarkastella kannattavuuseroihin vaikuttavia pysyviä tekijöitä.

Usein jako hyviin ja heikkoihin tehdään edellä kuvatusti sen muuttujan perusteella, jonka eroja sitten tarkastellaan. Vaikka äärimmäiset havainnot on jätetty pois, tällainen tarkastelu kuitenkin korostaa eroja ja ryhmittely tulisikin tehdä riippumattoman tekijän perusteella. Mikäli tilakokoluokan "suuri" ryhmäjako tehdään lehmämäärän perusteella, niin pienemmän 25 lehmän ja suuremman 40 lehmän ryhmän kannattavuuskertoimet ovat vastaavasti 0,67 ja 0,73 . Näin päädytään siis entistäkin pienempään kannattavuuseroon. Lähes vastaavaan kannattavuuseroon päädytään, jos käytetään keskituotosta. Yritysten tilakokoluokkien sisäiset kannattavuuserot ovat selvästi pienempiä kuin yleisesti ajatellaan.

Taloustohtorin Maa- ja puutarhatalous-verkkopalvelu (www.mtt.fi/taloustohtori) tarjoaa erittäin monipuoliset mahdollisuudet tarkastella eri luokittelevien tekijöiden (vuodet, eri alueluokittelut, tuotantosuunnat ja -haarat, tilakokoluokat) kombinaatioina muodostettujen tilaryhmien keskiarvotuloksia ja myös näistä eri perustein tehtyjä hyvät/heikot -ryhmiä ja niiden talouslaskelmia. 


\title{
Johdanto
}

Maatalousyritysten kannattavuudessa on suuria eroja. Osa niistä aiheutuu suoraan eri tuotantosuuntien päätuotteiden ja panosten hinnoista ja/tai tukieroista. Merkittävä kannattavuuseroja aiheuttava tekijä on myös tilakoko. Tämän lisäksi kannattavuuseroja aiheuttaa mm. tilan elinkaaren vaihe. Syyt havaittuihin kannattavuuseroihin on näissä tapauksissa ilmeisiä. Haastavampaa on hakea syitä kannattavuuseroihin silloin, kun tarkastellaan tilaryhmiä, joista edellä mainittuja tekijöitä on poistettu esimerkiksi jättämällä ne pois tarkastelusta. Näin päästään homogeenisempiin ja stabiilimpiin tilaryhmiin ja hakemaan todellisia tuotannosta aiheutuvia syitä kannattavuuseroihin.

\begin{abstract}
Aineisto
MTT Taloustutkimuksen toimesta neuvontajärjestöt keräävät ja MTT käsittelee ja tuottaa vuosittain mm. tutkimusta varten yritystason tutkimusaineiston, MTT:n kannattavuuskirjanpitoaineiston. Aineisto käsittää vuosittain noin 1000 tilan taloustiedot ja myös tuotantoprosessitietoja.

Seuraavassa tutkimusaineistona käytetään kannattavuuskirjanpitoaineiston tilivuoden 2008 maitotiloja. Tuotantosuuntamäärittely perustuu vakioituihin katteisiin ja EUmaataloustypologian mukaiseen tuotantosuuntamäärittelyyn. Pääsääntöisesti tässä esitettävät tulokset ovat painotettu Tiken vuosittain MTT:lle toimittaman kaikki Suomen maatilat sisältävän rakennetutkimusaineiston ja maatilarekisterin pohjilta muodostetun aineiston avulla. Painotuksen vuoksi tulokset on yleistettävissä kuvaamaan Suomen keskimääräistä tilannetta.

Tarkasteluun on käytetty MTT:n Taloustohtori -verkkosivuston julkista maa- ja puutarhatalous-verkkopalvelua sekä MTT:n sisäisessä käytössä olevaa analyysijärjestelmää, jolla kyetään tarkastelemaan tuloksia hyvin erilaisin luokitteluita käyttäen.
\end{abstract}

\section{Tulokset ja tulosten tarkastelu}

Maitotilojen kannattavuuskerroin on noussut neljä viimeistä vuotta ollen tilivuonna 2008 jo 0,62 eli yrittäjä sai työtunnilleen 62 prosenttia maataloustyöntekijän tuntipalkan perusteella lasketusta tavoitteesta. Maitotilojen kannattavuus nousi tilivuonna 2008 tuotantosuunnista parhaaksi, osin myös siksi että muiden tuotantosuuntien kannattavuus alentui 0,43:een.

Kannattavuustarkastelu perustuu kannattavuuskertoimeen, joka lasketaan jakamalla yrittäjäperheen työpanokselle ja pääomapanokselle korvaukseksi jäävä yrittäjätulo näille panoksille tavoitteeksi asetettujen palkka- ja korkovaatimusten summalla.

Maitotilojen kannattavuusvaihtelut ovat muita tuotantosuuntia pienempiä, joten kannattavuuserojen syiden etsiminen maitotiloilta on haastavampaa kuin muissa tuotantosuunnissa. Maitotiloista 50 prosentilla kannattavuuskerroin on $0,25: \mathrm{n}$ ja $0,75: \mathrm{n}$ välillä, kun hajonta on eräissä tuotantosuunnissa jopa kaksinkertainen tähän verrattuna. Vuonna 2008 maitotilojen tilakokojärjestys ja kannattavuusjärjestys olivat täysin samat. Mitä suurempi tila, sitä parempi kannattavuus keskimäärin oli. Kannattavuuskerroin vaihteli vuonna 2008 kuuden tilakokoluokan luokittelua käytettäessä 7 lehmän "melko pieni" -tilakokoluokan 0,43:sta 93 lehmän "erittäin suuri" tilakokoluokan 0,8:aan.

Kun maitotilan tuotantokustannukset suhteutetaan tuotettuun maitolitramäärään, niin nähdään samoin, että suuremmilla tiloilla tuotantokustannukset tuotantomääriin suhteutettuna ovat pienemmät. Suuret tilat kykenevät hyödyntämään suuruuden ekonomiaa. Tilakokoluokittainen kustannuserittely paljastaa, että kustannuseroja aiheuttaa mm. työkustannus, jonka osuus kustannuksista on pienemmillä tiloilla merkittävästi suurempi kuin suurilla tiloilla. Toisaalta pienillä tiloilla työvaltaisuuden vuoksi, vastaavasti poisto- ja korkokustannukset ovat suhteessa jonkin verran pienempiä kuin suurilla tiloilla.

Koska tilakoko jo sinänsä aiheuttaa kannattavuuseroja, mielenkiintoista on tarkastella, että onko yksittäisten tilakokoluokkien sisällä kannattavuusvaihtelua. Seuraavassa tarkastellaan esimerkinomaisesti tilakokoluokan "suuri" maitotiloja. Kunkin 135 maitotilan tulokset otetaan kes- 
kiarvolaskelmiin sillä painolla, millaista tilamäärää ne alueellaan edustavat tilakokoluokkaan kuuluvista Suomen yhteensä 3600 maitotilasta. Tämän tilakokoluokan kannattavuuskerroin oli vuonna 2008 keskimäärin 0,71 ja tiloilla oli keskimäärin 32 lehmää.

Kun jaetaan vuosittain tilakokoluokkaan "suuri" kuuluvat maitotilat kannattavuuskertoimen mukaan heikoimpaan ja parhaimpaan viidennekseen, on ryhmien kannattavuuskerrointen ero ollut vuodesta 2004 lähtien vuosittain lähes 1,3. Heikoimman ryhmän kannattavuuskerroin on ollut negatiivinen, $-0,1$ ja parhaimman noin 1,2 (kuvio 2). Heikomman ryhmän tiloissa on juuri investoineita, koska omavaraisuusaste oli keskimäärin 45 eli velkaa on suurin osa, 55 prosenttia, kokonaispääomasta.

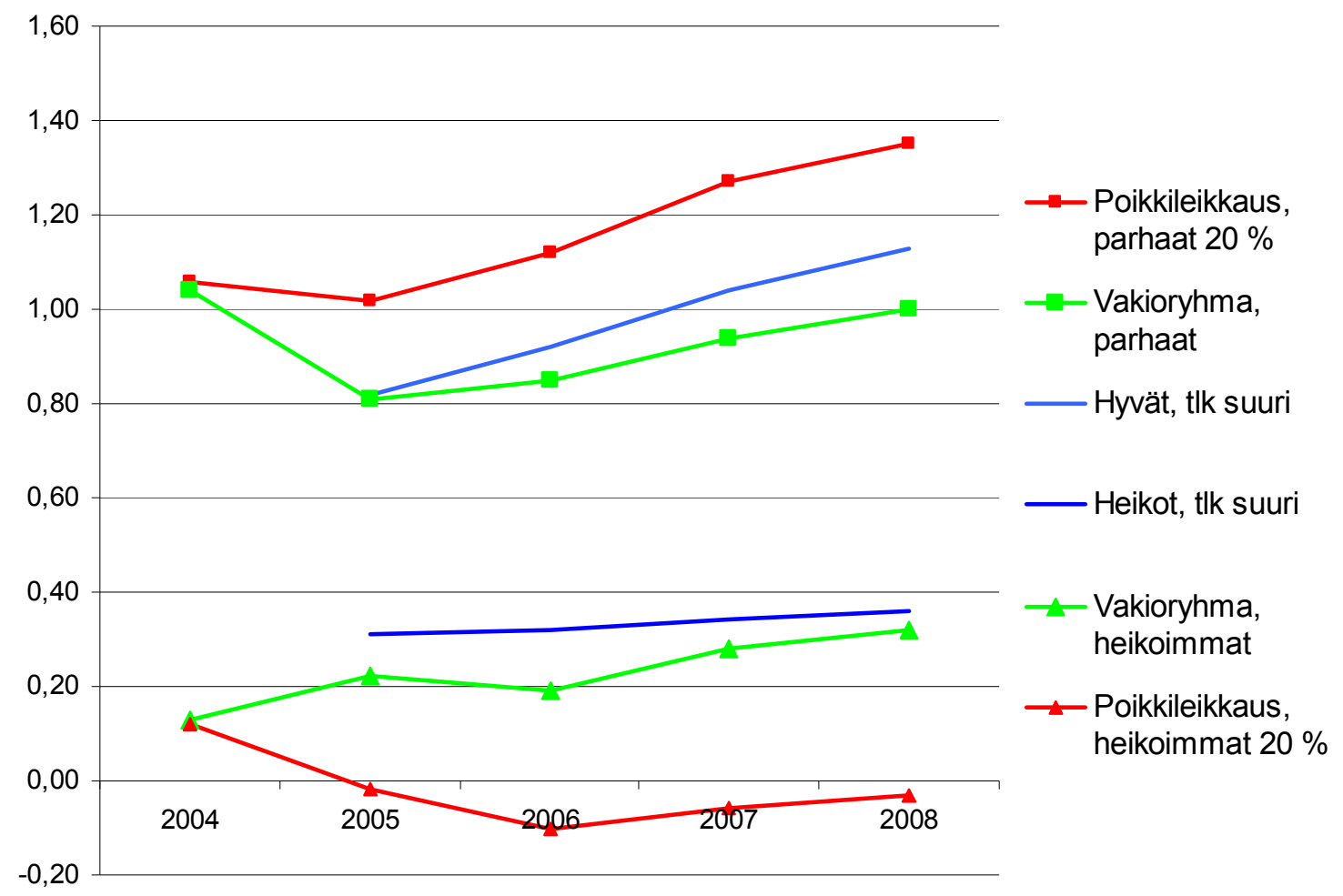

Kuvio 1. Maitotilojen kannattavuudeltaan parhaan $20 \%$ ja heikoimman $20 \%$ kannattavuus vuosittain sekä vuoden 2004 mukaisten ryhmien kannattavuuskehitys sekä tilakokoluokan suuri hyvät- ja heikotryhmien keskiarvot vuosittain.

Kun tarkastellaan näiden vuoden 2004 tilaryhmien tuloksia vuonna 2005, havaitaan, että heikomman viidenneksen kannattavuus on kääntynyt nousuun poisto- ja korkokustannustenkin alentuessa ja parhaimman viidenneksen kannattavuus on kääntynyt laskuun, koska hyvä kannattavuus on johtunut osin poikkeuksellisista onnistumisista. Osin satunnaisista tekijöistä aiheutunut tilaryhmien kannattavuusero kaventuukin vuoden 2004 0,91:stä jo vuonna 2005 noin 0,60 :een, säilyen tällä tasolla seuraavat vuodet. Kehityskulku on sama riippumatta siitä, että mistä vuodesta tarkastelu aloitetaan. Tämä osoittaa, että äärimmäisten viidennesten ja myös neljännesten poikkileikkaustarkastelu yliarvioi kannattavuuseroja, jotka siis johtuvat osin satunnaisista tekijöistä. Tarkastelu on myös tilastollisesti harhainen. Näin muodostettujen ryhmien perusteella ei löydy todellisia tuotannosta aiheutuvia syitä kannattavuuseroihin.

Pysyvämpiin vertailuryhmiin päästään, kun määritetään hyvät- ja heikot -ryhmät vuosittain siten, että jätetään molemmista ääripäistä kymmenen prosenttia tiloista pois ja otetaan kumpaankin ryhmään seuraavat 20 prosenttia tiloista. Molempiin ryhmiin tulee noin 25 kirjanpitotilaa ja molemmat ryhmät edustavat 720 maitotilaa. 
Kuviossa 1 on esitetty näin saatujen hyvän ja heikon ryhmän kannattavuustulokset vuosilta 2005 - 2008. Vuonna 2008 heikot -ryhmän kannattavuuskerroin oli 0,36 ja hyvät -ryhmän 1,13 eli kannattavuusero oli 0,77 . Kannattavuustulokset vastaavat samaa tasoa, mihin tiettynä vuonna muodostetut tilaryhmät kykenivät pysyväisluontoisesti. Heikot -ryhmän omavaraisuusaste on 65 prosenttia eli 10 prosentin "hännän" poistaminen jättää ryhmästä pois juuri investoineita yrityksiä.

Ryhmät pysyvät kannattavuustasoillaan pidempiaikaisesti ja niiden perusteella voidaan paremmin tarkastella kannattavuuseroihin vaikuttavia tekijöitä. Vertailuasetelma vastaa MTT:n Taloustohtorin -sivuston maa- ja puutarhatalous -verkkopalvelussa (www.mtt.fi/taloustohtori) nähtävissä olevia hajontatarkasteluita sekä kannattavuuskirjanpitotiloille palauteraporteissa lähettävää vertailuasetelmaa.

Edellä jako hyviin ja heikkoihin tehtiin perustuen kannattavuuskertoimeen, jonka eroja sitten tarkasteltiin. Vaikka tässä äärimmäiset 10 prosenttia tiloista onkin jätetty pois jakauman molemmista päistä, myös tämä tarkastelu korostaa kannattavuuseroja. Ryhmäjako tulisi tehdä riippumattoman, eksogeenisen tekijän perusteella, joita voisi olla tilakokoon tai esimerkiksi pääomarakenteeseen liittyvät muuttujat.

Mikäli tilakokoluokassa "suuri" maitotilat asetetaan suuruusjärjestykseen lehmämäärän perusteella ja tehdään ryhmäjako hyviin ja heikkoihin jättämällä sekä ylä- että alapäästä 10 prosentin ääripäät pois ja ottamalla seuraavat 20 prosenttia kumpaankin ryhmään, niiin pienemmän 25 lehmän ja suuremman 40 lehmän ryhmän kannattavuuskertoimet ovat 0,67 ja 0,73 . Kannattavuusero on selvästi pienempi, kun ryhmittely hyvät/heikot -ryhmiin ei perustu kannattavuuskertoimeen.

Tarkastelussa keskitytään jo "suuri" -tilakokoluokkaan ja lehmämäärä on toinen tilakokoon liittyvä muuttuja. Jos jako heikot/hyvät -ryhmiin tehdään vastaavasti keskituotoksen perusteella, niin heikossa 7500 litran ryhmässä kannattavuuskerroin on 0.76 ja 9200 litran ryhmässä selvästi korkeampi, 0,89. Eli tässäkin kannattavuusero on pieni verrattuna kannattavuuskertoimeen perustuvaan hyvät/heikot -ryhmittelyyn sekä erityisesti kannattavuuskertoimeen perustuvaan heikoin/paras viidennes -ryhmittelyyn. Samansuuntaisen tuloksen antavat lehmämäärän ja keskituotoksen lisäksi lähes mitkä tahansa muuttujat. Muiden muuttujien kuin kannattavuuskertoimen käyttö ryhmittelyssä osoittaa, että yritysten tilakokoluokkien sisäiset pysyvät kannattavuuserot ovat selvästi pienempiä kuin yleisesti ajatellaan.

Jatkossa tarkastellaan keskituotokseen perustuvien hyvät/ ja heikot -ryhmien tuotto- ja kustannusrakenteiden eroja. Ryhmien kannattavuuskertoimien varianssit olivat eri suuret. Ryhmien kannattavuuskerroin -keskiarvot erosivat T-testin mukaan tilastollisesti merkitsevästi toisistaan. Kuviossa 2. on tilakokoluokan "suuri" maitotilat luokiteltuna keskituotoksen perusteella hyvät/heikot -ryhmiin. Kuviossa on ryhmien kustannusrakenteiden lisäksi myös kokonaistuotot. Molemmissa ryhmissä on noin 31-32 lehmää ja tuotantokustannukset ovat kutakuinkin samansuuruiset ja myös kustannusrakenne on hyvin samantyyppinen. Hyvät -ryhmässä keskituotos on vuonna 2008 kuitenkin 9200 litraa eli noin 1700 litraa suurempi kuin heikot -ryhmässä.

Mikäli olisi tarkasteltu äärimmäisiä viidenneksiä, ryhmien keskituotosero vuonna 2008 olisi 4000 litraa eli yli kaksinkertainen. Paneelitarkastelu vuodesta 2004 lähtien kuitenkin näyttää tässäkin, että keskituotoserot eivät ole pysyviä. Vuoden 2004 ero, 3300 litraa, supistuu jo seuraavana vuonna 2500 litraan sekä edelleen vuoteen 2008 mennessä 2000 litraan. Vastaavalla tavalla tulee käymään vuoden 2008 äärimmäisten viidennesten keskituotoserolle tulevina vuosina eli ero supistuu.

Koska molemmissa ryhmissä lehmämäärä on likimain sama, hyvät -ryhmässä korkeamman keskituotoksen myötä saatavien korkeampien tuottojen myötä kustannukset kyetään kattamaan paremmin ja kannattavuus on näin parempi. Keskituotoksen merkitys kannattavuuseron aiheuttajana/ selittäjänä johtuu tässäkin osin siitä, että siitä tehdään tärkeä "selittäjä" käyttämällä sitä hyvät/heikot - ryhmittelyssä. Sinänsä kustannustekijöistä johtuvia syitä ryhmien keskituotos-eroon ei kuvion 1. kustannusjaottelusta voi havaita. Kustannuserät on ryhmitetty tässä melko suuriksi ja mahdollisesti yksityiskohtaisempi kustannusryhmittely voisi paljastaa syitä. 


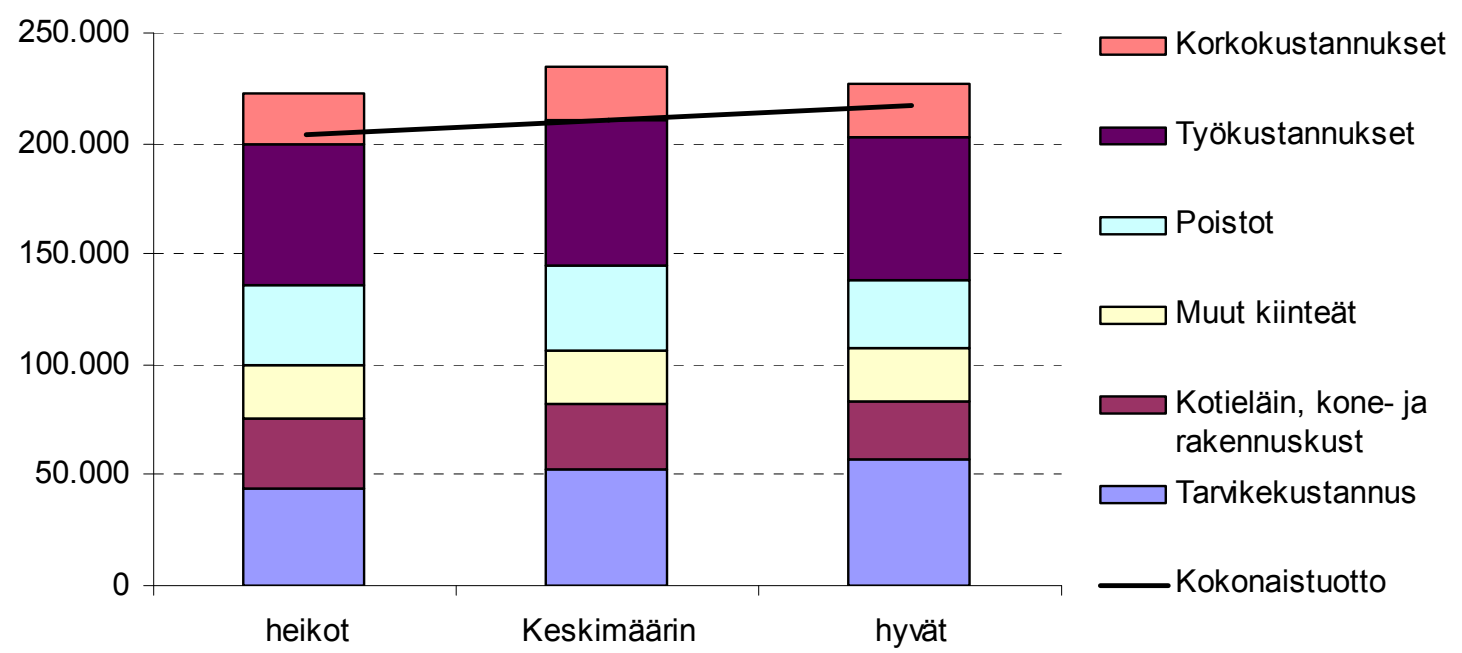

Kuvio 2. Suurten maitotilojen kustannusrakenne keskituotoksen mukaisissa heikot/hyvät -ryhmissä.

\section{Johtopäätökset}

Syyt kannattavuuseroihin on nähtävissä silloin, kun ne ovat ilmeisiä eli vertaillaan eri tuotantosuuntia, eri tilakokoluokkiin kuuluvia tai eri elinkaaren vaiheessa olevia tilaryhmiä keskenään. Usein näiden vertailujen suuretkin kannattavuuserot yleistetään koskemaan koko maataloussektoria ja samalla maatalousyritysten kannattavuuseroista annetaan todellista suurempi kuva.

Kun verrataan edellä mainittujen tekijöiden suhteen homogeenista tilajoukkoa, löytyy tilajoukosta edelleen kannattavuuseroja. Mikäli tarkastelu perustuu kannattavuudeltaan parhaan ja heikoimman viidenneksen (tai neljänneksen) tarkasteluun, havaitaan kuitenkin kannattavuuseroja, jotka puolittuvat jo seuraavana vuonna. Tarkasteluista tulisikin poistaa kannattavuudeltaan parhaimmat ja heikoimmat tilaryhmät, jolloin saadaan kannattavuusanalyyseihin stabiilimmat vertailuryhmät, joiden kannattavuuserot säilyvät seuraavina vuosina. Tästäkin huolimatta kannattavuuserot korostuvat ja jako vertailtaviin ryhmiin tulisikin tehdä eksogeenisten tekijöiden suhteen. Tällöin ryhmien kannattavuuserot supistuvat entisestään ja erojen vähäisyys käy selville. Syyt kannattavuusvaihteluun eivät ole enää selviä ja helposti kuvailevan tilastotieteen keinoin löydettävissä. Kannattavuuserojen syiden löytäminen vaatii tilastollisia analyysejä, ekonometriaa, tekoälypohjaisia menetelmiä jne.

Suomen maatalouden taloustutkimuksessa resurssit ovat kuitenkin niin pienet, että ei kyetä tuottamaan vuosittain analyysejä eri alueiden, tuotantosuuntien, tilakokoluokkien jne. tarpeisiin ja nopeasti muuttuviin taloudellisiin tilanteisiin. Ainoa mahdollisuus olisi tuottaa verkkopalveluja tai muita IT-järjestelmiä, jotka vähintään tyydyttävällä tarkkuudella ja luotettavuudella tuottaisivat automaattisesti analyysejä ja raportteja eri yritysryhmien käyttöön. Näissä tulisi lisäksi suuntautua panos- ja tuotehintavaihteluiden lisääntyessä entistä enemmän erilaisiin simulointeihin sekä ennustamiseen, jotta tuleviin muutoksiin kyettäisiin varautumaan mahdollisimman aikaisin. 